\title{
Zeeuwse reacties op de Acte van Seclusie
}

\section{J. H. KLUIVER}

De door Holland in 1648 doorgedreven vrede van Munster betekende voor Zeeland een ernstige politieke nederlaag. Nooit moest het kleine gewest op smadelijker wijze ondervinden dat het een satellietstaatje van zijn machtige noorderbuur was geworden. Na 1648 brak een periode aan, waarin Hollands suprematie in de Republiek onbetwistbaar was. Dit betekende echter niet dat Zeeland en de andere provincies Hollands leiding zonder meer accepteerden. Menigmaal klonken in de vergaderingen van de Staten-Generaal heftige protesten wanneer Holland onvoldoende rekening hield met de belangen van de andere bondgenoten. Een van die gelegenheden was het geschil over de Acte van Seclusie, die Holland begin juni 1654 met Cromwell sloot om de vrede met Engeland te verzekeren. Deze in het geheim overhandigde acte wekte hevige verontwaardiging bij de andere provincies, met name bij Zeeland, Friesland en Groningen. Aan de rol van Zeeland in deze kwestie wil ik in deze bijdrage aandacht besteden.

Voor een goed begrip van de houding van Zeeland is het noodzakelijk wat verder terug te gaan, tot het begin van de verwikkelingen in Engeland. Hoewel de publieke opinie in de Republiek aanvankelijk op de hand van het parlement was - zo noemde men het tegen koning en Hogerhuis in verzet gekomen Lagerhuis - voerden Holland en Zeeland in het begin van de jaren veertig een strikte neutraliteitspolitiek. Zeeland had zich hiertoe verplicht na een 'bezending' vanuit Holland in $1642^{1}$. Men wenste op geen enkele manier een voorkeur voor één van beide partijen te laten blijken. Deze politiek werd ingegeven door handelsbelang: beide provincies hadden groot belang bij een onbelemmerde handel en scheepvaart op Engeland, die ook voor Zeeland, ondanks het vertrek van de Merchant Adventurers uit Middelburg in 1621, nog van grote betekenis waren. De omvang van de handel en scheepvaart vanuit Zeeland op Engeland is moeilijk te bepalen, maar afgaande op de verdeling van de convooidiensten moet deze ongeveer $20 \%$ van de totale Zeeuwse overzeese handel en scheepvaart hebben bedragen ${ }^{2}$.

Het kostte de Staten van Zeeland moeite de neutraliteitspolitiek te handhaven. De sympathie van het calvinistische volksdeel ging uit naar het parlement. In 1643

1. Notulen van de Staten van Zeeland (Not. Zeeland), 24 oktober 1642.

2. Advies van de admiraliteit aan de Staten van Zeeland, 2 februari 1628, Rijksarchief in Zeeland (RAZ), Handschriftenverzameling nr. 34. 
ontstond zelfs een vrij hevig conflict over de betrekkingen met Engeland tussen de Staten van Zeeland en de classicale vergaderingen van de provincie. Deze waren zonder toestemming van de Staten te Middelburg bijeengekomen en hadden 'troostbrieven' aan de kerken in Engeland en Schotland afgezonden. In een brief aan de kerk van Schotland verzochten de classes deze er voor te willen waken dat de Engelse kerk via het episcopale systeem, de door de presbyterianen zo verfoeide 'geestelijcke regeringhe ${ }^{\prime 3}$, aan het katholicisme ten prooi zou vallen ${ }^{4}$. De Statenvergadering beschouwde deze correspondentie als een inmenging in en een aantasting van haar neutraliteitspolitiek. Zij eiste inzage van de bewuste brieven, wat de classes weigerden ${ }^{5}$. Daarmee groeide het conflict uit tot een competentiekwestie tussen kerk en staat, waarvan de afloop in dit verband niet ter zake doet. Ondanks hun sympathie voor de partij van het parlement wezen de kerken actieve inmenging in het Engelse conflict echter van de hand: de classis Walcheren besloot 5 maart 1643 zowel Frederik Hendrik te wijzen op de grote opspraak en schade die zijn houding het Oranjehuis berokkende, als de Staten-Generaal te verzoeken de toevoer van ammunitie aan het parlement te willen verhinderen ${ }^{6}$.

De terechtstelling van Karel I in 1649 bracht in de publieke opinie in Zeeland, evenals elders in de Republiek, een grote ommekeer teweeg ${ }^{7}$. Men had voor het optreden van de koning weinig sympathie gehad, maar in de ogen van de calvinisten was hij toch een 'gezalfde des Heeren' aan wie men zich niet straffeloos kon vergrijpen. Hoe de stemming in Zeeland was illustreert een brief van de Middelburgse regent Hendrick Thibaut aan stadhouder Willem II. Thibaut condoleert de prins in deze brief met de executie van diens schoonvader. Hij hoopt op een rechtvaardige straf 'over dese barbaren, die van nu aen een vervloeckinghe sijn van alle ingesetenen van onse provincie ende specialijck van onse stad' ${ }^{\prime}$.

Het was dan ook niet van harte dat Zeeland zich begin januari 1651 met Holland voor erkenning van de republiek Engeland verklaarde, maar het was om 'verscheijden redenen en interesten nodig' ${ }^{\prime}$. Diezelfde interesten kwamen echter in het geding met de uitvaardiging van de Navigation Act door Cromwell in 1651. Deze was zeer schadelijk voor de handel en scheepvaart vanuit Holland en Zeeland op Engeland. Voor Zeeland, dat sinds de vrede met Spanje toch al met een vermindering van zijn welvaart te kampen had, kwam deze maatregel extra hard aan, en de ver-

3. Zo noemde een deputatie uit de classis Walcheren het episcopale systeem. Not. Zeeland, 22 maart 1643 .

4. L. van Aitzema, Saken van Staet en Oorlog (Amsterdam, 1669) III, 929.

5. Not. Zeeland, juni 1643.

6. RAZ, Archief van de classis Walcheren, nr. 3, acta 5 maart 1643.

7. Vergelijk D. Grosheide, Cromwell naar het oordeel van zijn Nederlandse tijdgenoten (Amsterdam, 1951).

8. Koninklijk Huisarchief, Inventaris A 15 XI-C, nr. 7.

9. Resolutie Staten-Generaal, 7 januari 1651. 


\section{J. H. KLUIVER}

liezen ter zee in 1652 maakten dan ook een ware oorlogsstemming gaande. Zeeland dat in 1648 nog had beweerd dat de vloot kon worden opgelegd en de zee beveiligd met kaperschepen, liep nu in de voorste gelederen om de zeemacht uit te breiden. Zonder enige aarzeling keurden de Staten credieten goed voor de bouw van vijftig schepen om de Engelsen te lijf te gaan, terwijl enige steden zelfs tot 150 of 200 schepen wilden gaan ${ }^{10}$. Aitzema geeft in zijn Saken van Staet en Oorlog de stemming die in Zeeland heerste kernachtig weer:

Het was staert hier, staert daer [zo noemden zij de Engelsen]. Elck Zeeuw scheen een staert in de mondt te hebben, gelijck men de muys in de mondt van de kat schildert. Het schenen rechte saevi. Ende enighe geloofden dat Hector een Zeeuw was geweest omdat Virgilius seijdt: Saevus ubi Aeacidae telo jacet Hector ${ }^{11}$.

Het verloop van de oorlog had zijn weerslag op de binnenlandse politiek. Naarmate de oorlog met Engeland ongunstiger verliep ging een luider roep op naar leiderschap door een Oranje. 21 september 1652 besloten de Staten van Zeeland in de Staten-Generaal aan te dringen op benoeming van de prins van Oranje tot kapiteinen admiraal-generaal en aanstelling van de Friese stadhouder Willem Frederik tot luitenant-generaal. Een deputatie uit de Staten van Holland trachtte tevergeefs dit besluit te verhinderen ${ }^{12}$. Het verloop van de bezending is tekenend voor de politieke situatie in Zeeland op dat moment. De Hollandse afgevaardigden, onder wie Johan de Witt, werden door een voor de Statenzaal samengestroomde menigte zo zeer bedreigd dat zij voor hun leven hadden te vrezen. Aangemoedigd door De Witt wezen zij echter een voorstel om enige predikanten de menigte te laten kalmeren van de hand, wat er ook van mocht komen. Zij verzochten de Statenvergadering zich niet door de agitatie van het volk te laten beïnvloeden ${ }^{13}$. Hoewel de Staten van Zeeland verklaarden dat van enige beïnvloeding geen sprake was, hadden zij bij hun besluit wel degelijk rekening gehouden met de publieke opinie. Aitzema merkt dan ook cynisch op: "t was politijckelijck gedaen, want sij verweckten ontsag voor de magistraten en aensien en liefde bij de Gemeente ${ }^{14}$.

Het voorstel de prins van Oranje tot opperbevelhebber te benoemen had overigens met moeite een meerderheid gekregen in de vroedschap van Middelburg, zonder wier steun een dergelijk voorstel in de Statenvergadering geen kans maakte. Sinds 6 juni 1651, toen de leiders van de extreem prinsgezinde factie, Hendrick Thibaut, Jacob Lansbergen en Paulus Jansz Serooskerke na een volksoproer uit de vroed-

10. Not. Zeeland, 24 februari 1652.

11. Aitzema, Saken van Staet, III, 912.

12. Not. Zeeland, 21 september 1651; Aitzema, Saken van Staet, III, 745.

13. Brieven geschreven en gewisseld tusschen den Heer Johann de Witt ende gevolmaghtighden van den Staedt der Verenighde Nederlanden ('s-Gravenhage, 1723-1725) V, 11, 12; J. Wagenaar, Vaderlandse Historie (Amsterdam, 1794) XII, 227, 228.

14. Aitzema, Saken van Staet, III, 746. 
schap waren gestoten, had de factie van Apollonius Veth een meerderheid in de vroedschap van Middelburg ${ }^{15}$. De factie van Apollonius Veth is enigszins te vergelijken met de staatsgezinde facties in de Hollandse steden. Veth en de zijnen waren voorstanders van een goede verstandhouding met Holland - volgens sommige berichten was het oproer van 1651 in overleg met Hollandse Staatsgezinden ontketend - en wensten voorlopig geen aanstelling van een stadhouder of kapiteingeneraal. We mogen echter de tegenstelling tussen de Zeeuwse facties niet met de Hollandse factieverhoudingen op één lijn stellen of al te ideologisch interpreteren. Veth's factie had tot 1650 evenzeer de politiek van stadhouder Willem II gesteund, terwijl Thibaut na zijn terugkeer in de vroedschap van Middelburg (in 1662) een veel gematigder koers zou volgen. De staatsgezinde opvattingen van eerstgenoemde factie respecteerden de Zeeuwse belangen evenzeer als de orangistische doelstellingen van laatstgenoemde factie hoofdzakelijk het provinciaal belang tot uitgangspunt hadden.

Apollonius Veth had in 1651 de verbanning van Thibaut weten te bewerkstelligen, die door het Hof van Holland overigens niet erkend was, maar desondanks had zijn factie moeite om de magistraat van Middelburg te beheersen. Dit bleek al vrij spoedig bij de gang van zaken rondom het voorstel tot benoeming van een kapitein- en luitenant-generaal. Het besluit van de vroedschap dit voorstel bij de Staten van Zeeland in stemming te brengen betekende in feite een eerste nederlaag voor Apollonius Veth. Regenten die hij tot zijn medestanders rekende bleken achteraf toch de Oranjepartij welgezind te zijn. Johan de Mauregnault, die de Friese stadhouder van de gang van zaken rondom de designatie op de hoogte hield, rapporteerde 23 augustus 1652 dat burgemeester Jacob de Kuyser het voorstel met een lijkbleek gezicht in de vroedschap ter tafel had gebracht en door de tegenpartij heftig was bestreden ${ }^{16}$. Veth zag geen kans de zaak tegen te houden en verliet voortijdig de vergadering, waarna het voorstel van De Kuyser zonder moeite werd aangenomen. 'Zij zijn met couragie in haer kot gejaagd', zo constateerde De Mauregnault met voldoening in zijn brief aan Willem Frederik.

In de andere steden was de staatsgezinde factie veel zwakker. In Zierikzee en Goes had deze na 1650 enige invloed, maar door de oorlog kregen de Orangisten

15. Gegevens over deze factieverhoudingen onder meer in: 'Brief aen Adriaen Veth Raedtpensionaris van Zeelandt dienende tot een sedige verantwoordinge van de eere van Karel Roorda de Oude tegens de publijcke blame hem op de hals gesmeten in seeckere propositie', in: W. P. C. Knuttel, Catalogus van pamfletten, tractaten etc. betreffende de geschiedenis van Nederland, nr. 8369; Memorie van M. de Turenne d.d. 1664, Archives du Ministère des Affaires Etrangères, Parijs (AAEP), Correspondance Politique, Hollande, LXXIV, nr. 31, f. 88; D'Estrades aan Lodewijk XIV, 26 september 1663, Memoires et negociations de monsieur comte d'Estrades (Brussel, 1709) 210.

16. Johan de Mauregnault aan Willem Frederik van Nassau, 23 augustus 1652, J. W. van Sijpesteijn, Geschiedkundige bijdragen ('s-Gravenhage, 1865) I, 202-208. 


\section{J. H. KLUIVER}

ook daar de wind in de zeilen. Vlissingen en Veere waren zonder meer prinsgezind. $\mathrm{Zij}$ hadden in 1650 zelfs geweigerd de magistraatsbestelling in eigen hand te nemen. Het verloop van de oorlog wakkerde de stemming van Oranjegezindheid verder aan. De bevolking was zeer gebeten op de Engelsen en eiste de vernietiging van de Engelse republiek. Wie op straat geen Oranje droeg kon op een warm onthaal rekenen. Oranjewimpels wapperden van de torens en het 'leve de prins' klonk door de straten ${ }^{17}$. Justus de Huybert, secretaris van Zierikzee, schreef in een brief aan Johan de Witt 'dat alles alreede is ende noch verder tot extremiteijten staet uyt te bersten, want met Orangie en Nassau wil men hier sterven ${ }^{18}$.

Ook in regentenkringen waren zulke geluiden te horen. De Huybert, die zich aanvankelijk vrij gematigd uitliet, had in 1653 geen goed woord meer over voor het Engeland van Cromwell ${ }^{19}$. Toch waren er ook voorstanders van een vergelijk met Engeland. De kooplieden, die grote schade ondervonden van de oorlog, waren bereid op minder gunstige voorwaarden vrede te sluiten ${ }^{20}$.

Zeeland bracht het voorstel tot designatie 23 juni 1653 in de Staten-Generaal en werd hierin bijgevallen door Friesland en Groningen. Holland stelde zich heftig te weer tegen het voorstel in een vertoog aan de provincies tegen de aanstelling van een kapitein en luitenant-generaal, zodat het geen schijn van kans maakte. In dit jaar verzwakte de positie van de staatsgezinde facties in Zeeland door het overlijden van Apollonius Veth ${ }^{21}$. Het wegvallen van deze leidersfiguur, door een correspondent van Thurloe 'un grand republicain' genoemd, gaf de Orangisten een vastere greep op de politiek van de provincie ${ }^{22}$.

Tegen de in het voorgaande aangegeven achtergronden is een felle reactie van Zeeland op de Acte van Seclusie begrijpelijk. Al in november 1653 had Zeeland met de andere provincies een voorstel van Cromwell in deze richting van de hand gewezen. Cromwell had daarop een 'temperament' voorgesteld, waarbij werd bepaald

17. Gentillot aan Servien, 23 juli 1653, AAEP, CP, Hollande, LUI, nr. 53, f. 40; A Collection of State Papers of John Thurloe (Londen, 1742), II, 363, 364.

18. Justus de Huybert aan Johan de Witt, 2 juli 1653, in: R. Fruin en G. W. Kernkamp, ed., Brieven van Johan de Wit, 1650-1672, 1,1650-1657(1658). Werken Historisch Genootschap, derde serie, XVIII (Amsterdam, 1906) 54.

19. Justus de Huybert aan Johan de Witt, 7 maart 1653, ibidem, 51.

20. Gentillot aan Servien, 30 juli 1653, AAEP, CP, Hollande, LIII, nr. 27, f. 50: 'ceux qui sont purement marchants de la bourse comme on dict voudroyent la paix, tout le reste veut qu'on prenne courage, qu'on contribue, qu'on mette tout pour ruyner cette republique d'Angleterre'.

21. Veth overleed 12 juli 1653 . Volgens de 'Sleutel op de Burleske Notulen van Zeeland', RAZ, Handschriftenverzameling, nr. 34, was dit een indirecte gevolg van het optreden van Hendrik Thibaut. Na zijn verbanning waagde deze het op een zondag in Middelburg terug te keren en naast Veth in de kerk te gaan zitten. Voordat deze echter maatregelen had kunnen treffen had Thibaut de stad al weer verlaten, waarover Veth zich dermate zou hebben opgewonden dat hij tijdens een bijeenkomst over deze zaak zijn wijnroemer zo driftig neerzette dat deze brak en hem dusdanig aan een polsslagader verwondde, dat hij overleed.

22. Thurloe Papers, I, 266. 
dat een toekomstig stadhouder en kapitein-generaal de vrede met Engeland zou moeten bezweren; hij bleef echter van Holland een verklaring tot uitsluiting van de Oranjes uit het ambt van stadhouder en kapitein-generaal verlangen. De Staten van Holland besloten in hun vergadering van 4 mei 1654 een dergelijke verklaring aan Cromwell te verstrekken. Van Beverningh en Nieuwpoort, de door Holland beschikbaar gestelde ambassadeurs, kregen echter de opdracht alvorens de acte te overhandigen eerst nog alle moeite te doen Cromwell van zijn eis tot seclusie te laten afzien.

Hoewel alle leden van de Staten van Holland een eed tot geheimhouding hadden afgelegd kwamen de andere provincies al vrij snel van de inhoud van de Acte van Seclusie op de hoogte. De gedeputeerden van Zeeland gaven eerst in een bijeenkomst met de Staten van Holland, waar zij onder een voorwendsel toegang hadden verzocht, blijk van hun misnoegen over de Acte van Seclusie, daarna gezamenlijk met Friesland en Groningen in de Staten-Generaal, terwijl de andere provincies er geen twijfel over lieten bestaan dat zij een dergelijke lastgeving zouden ontvangen $^{23}$. Volgens de Franse ambassadeur Chanut was Holland aanvankelijk wat uit het veld geslagen door deze algemene en heftige afkeuring van zijn gedragslijn ${ }^{24}$. Het optreden van de provincies had in zoverre succes dat Holland Van Beverningh en Nieuwpoort gelastte de Acte niet zonder nadere lastgeving te overhandigen en intussen al het mogelijke te doen om Cromwell van zijn eis te laten afzien. Men besloot echter in de Staten-Generaal geen opening van zaken te geven of enige verantwoording af te leggen ${ }^{25}$.

De eerstvolgende weken ging het steekspel tussen Friesland en Holland met ongewone heftigheid verder, terwijl de Zeeuwse gedeputeerden verklaarden een speciale lastgeving te zullen afwachten. De Friese afgevaardigden verklaarden in de vergadering van 18 mei dat de Staten van Holland 'soo doende den Heere Prince, en sijne descendenten soecken uyt te royen ende te dempen', en dat de prins door deze uitsluiting werd gebrandmerkt, een schande die zelfs iemand met een 'afgebrande conscientie' niet zou kunnen dragen. Aan het einde van hun betoog bezwoeren zij dat de beenderen van prins Willem I over een zo grote ondankbaarheid wraak zouden roepen. Hoewel het in de Staten-Generaal niet altijd even wellevend toeging waren dit wel zeer buitensporige bewoordingen. Holland beklaagde zich in een protest dan ook dat een dergelijke manier van spreken blijk gaf van een 'gealtereert en getransporteert gemoed'. Zelfs onder 'geciviliseerde mensen' in het particulier was zoiets niet gebruikelijk ${ }^{26}$. Toch maakten deze protesten weinig indruk omdat Holland

23. Fruin en Kernkamp, Brieven van Johan de Witt, I, 159, 160.

24. Chanut aan de Brienne, 14 mei 1654, AAEP, CP, Hollande, LII, nr. 59, f. 205: 'Ceux de Hollande parurent un peu mortifiez et estonnez par une detestation si generale de leur conduite'.

25. Secrete resolutiën van de Staten van Holland, 9, 10 mei 1654.

26. Resoluties Staten-Generaal, 18 mei 1654. 


\section{J. H. KLUIVER}

wel begreep dat Zeeland en Friesland niet tot het uiterste zouden gaan, nu de handel met Engeland na het tekenen van de vrede weer op gang was gekomen. Wel vreesde men dat het optreden van de provincies het verzet dat binnen de eigen provincie tegen de Acte van Seclusie bestond zozeer zou doen toenemen, dat de Acte zou moeten worden herroepen ${ }^{27}$.

In hun juni-vergadering beraadden de Staten van Zeeland zich op een officiële reactie op Hollands handelwijze. Op voorstel van Middelburg dat de afzonderlijke onderhandeling tot uitsluiting van de jonge prins 'van seer grooten insight en bedencking' achtte, werd een commissie benoemd tot onderzoek van alle stukken die op de zaak betrekking hadden. Deze bracht enkele dagen later rapport uit en op haar advies kreeg de secretaris der Staten de opdracht tot. het opstellen van een 'welgeraisonneerde deductie' 28 .

Het is opvallend dat niet de raadpensionaris Johan de Brune, maar de secretaris Adriaen Veth de opdracht tot het opstellen van de deductie kreeg. De persoonlijke inzichten van beide functionarissen hebben hierbij zeker geen rol gespeeld. De Brune was de Oranjepartij ongetwijfeld meer toegedaan dan Adriaen Veth, die kort na de verandering in de vroedschap van Middelburg in 1651 door de factie van zijn broer ApoUonius Veth als candidaat voor de functie van secretaris van de provincie naar voren was geschoven ${ }^{29}$. De oorzaak van deze keuze moet dan ook eerder worden gezocht in de omstandigheid dat De Brune een niet al te krachtige figuur was, wie het ontbrak aan voldoende moreel overwicht en politieke handigheid om de Statenvergadering in dergelijke gewichtige zaken tot een eensluidend standpunt te brengen. De Brune was een bekwaam literator, maar bepaald geen gewiekst politicus $^{30}$. Adriaen Veth daarentegen was een sterke persoonlijkheid, een bekwaam spreker, een 'harangueur', die op indringende wijze zijn standpunt aan zijn gehoor wist op te leggen ${ }^{31}$. Het disputeren zat hem in het bloed: volgens de karakterschets van de Zweedse resident Appelboom was hij zelfs 'un peu trop contredisant et picquant'.

Al eerder had Veth de provincie goede diensten bewezen. Nog voor zijn benoeming tot secretaris op 10 juni 1651 was hij gedeputeerd naar de Grote Vergadering van 1651, waar hij namens de Staten van Zeeland het woord voerde en onder meer

27. Chanut aan De Brienne, 28 mei 1654, AAEP, CP, Hollande, LII, nr. 66, f. 228.

28. Not. Zeeland, 12, 16 juni 1654.

29. Ibidem, 10,11 juni 1651; Justus de Huybert aan Johan de Witt, Fruin en Kernkamp, Brieven van Johan de Witt, I, 15, 16.

30. Typerend is bijvoorbeeld een uitlating van Justus de Huybert over De Brune naar aanleiding van diens reactie op een voorstel de Statenvergadering te manipuleren 'de goede ziele staet als bedwelmt en kijckt'.

31. Karakterschets van Adriaen Veth door de Zweedse resident Appelboom in G. W. Vreede, Inleiding tot eene geschiedenis der Nederlandse diplomatie (Utrecht, 1856) tweede gedeelte, bijlage XXXIV, 144. 
de bekende propositie tegen de corruptie in de Republiek hield. Daarmee legde hij in de Staten-Generaal een eerste proef af van zijn oratorisch talent. Voor het presenteren van de Deductie in 1654 werd hij speciaal afgevaardigd. Toen Zeeland na de restauratie van de Stuarts in Engeland in 1660 weer eens een poging deed Holland tot designatie van het opperbevel op de jonge prins te bewegen, was hij het weer die de zaak in de Staten-Generaal moest bepleiten. Deze rede, die ook algemeen werd geroemd, zal hierna nog ter sprake komen.

$\mathrm{Na}$ het overlijden van Johan de Brune in 1658 werd Adriaen Veth tot raadpensionaris benoemd. Dat hij een vrij grote invloed op de Statenvergadering had blijkt indirect bij het aanstellen van zijn opvolger na zijn overlijden in 1663 . Hoewel de Statenvergadering Veth uitbundig prees wegens de goede en trouwe diensten die hij aan de provincie had bewezen meende deze toch maatregelen te moeten nemen tegen een al te grote zelfstandigheid van de raadpensionaris: in de nieuwe instructie werd een bepaling opgenomen dat de pensionaris steeds met 'ongedeckten hoofde' zou moeten adviseren, ten teken dat hij dienaar van de Staten was, en 'tot respect van dese tafel'. Jaar voorjaar zou worden nagegaan of geen der bepalingen van de instructie in onbruik was geraakt ${ }^{32}$.

Dank zij het bewaard blijven van een bundel aantekeningen van Adriaen Veth is het mogelijk het ontstaan van de Deductie te volgen. Eerst heeft hij alle mogelijke argumenten bijeengezocht onder het opschrift 'Notanda op de resolutie van Hollant'. In een tweede versie zijn deze overzichtelijk gerangschikt, en daaruit is vervolgens het concept samengesteld. Niet alle ingrediënten zijn uiteindelijk gebruikt; alle argumenten waren ook niet even sterk. Zo bijvoorbeeld

of oock eene van de provinciën wel vermach te resolveren van soo een zake van importantie ter generaliteijt met zijn stemme te sullen beletten of deliberatie dienaengaende te turberen.

Zo'n argument kon Zeeland, dat zowel in 1609 als in 1648 had getracht het bestand respectievelijk de vrede met tegenstemmen te verijdelen, niet aandragen. Ook een van ressentiment getuigende opmerking 'dat daarmee bij Hollant wert geusurpeert een superioriteijt over de andere provintien' komt in de latere versies niet meer voor $^{33}$.

De Statenvergadering accepteerde de Deductie zoals ze door Veth was opge$\operatorname{steld}^{34}$. De enige verandering die plaatsvond was een gevolg van de gewijzigde omstandigheden. Men had aanvankelijk van Holland willen eisen dat het niet alleen volkomen opening van zaken zou geven maar ook de aan Van Beverningh en Nieuwpoort gegeven last zou intrekken. Tijdens de behandeling van de Deductie kwam

32. Not. Zeeland, 31 januari, 18 maart 1664.

33. RAZ, Verzameling Verheije van Citters, nr. 123b.

34. Not. Zeeland, 1654, bijlage 1-13. 


\section{J. H. KLUIVER}

echter het bericht dat de Acte van Seclusie aan Cromwell was overhandigd. 'De sake niet meer in sijn geheel sijnde' besloot men nu de Deductie te laten eindigen met een verzoek tot genoegdoening en een verklaring dat Zeeland onschuldig wenste te blijven aan de onheilen die uit Hollands optreden zouden kunnen voortkomen $^{35}$.

Het resultaat van Veth's inspanning was een stuk dat strookte met zijn reputatie als redenaar. Waarschijnlijk niet zonder opzet heeft hij de formeel juridische redeneringen met meer gevoelsmatige argumenten afgewisseld. Aan het begin worden artikel negen en tien van de Unie van Utrecht aan de orde gesteld. Volgens artikel tien was het de afzonderlijke provincies niet toegestaan 'confederatien ofte verbonden' met vreemde mogendheden te sluiten. Veth acht Hollands handelwijze in strijd met deze bepaling. Hij beschouwt echter niet de Acte van Seclusie als een overeenkomst met een vreemde mogendheid, maar het onderling 'verbant ende concert' dat daaraan moest zijn voorafgegaan, aangezien zonder een dergelijke overeenkomst geen noodzaak zou hebben bestaan de acte nog na de ratificatie van de vrede uit te leveren. Holland zou ook in strijd met artikel negen van de Unie hebben gehandeld. Volgens dit artikel mocht over zaken van bestand of vrede slechts met eenparigheid van stemmen worden beslist. Hollands optreden was daarmee in strijd omdat het met de belofte tot seclusie in feite over de vrede beschikte.

Daarna wordt de ondankbaarheid tegenover het Oranjehuis ten tonele gevoerd. De Nederlanden hebben steeds 'hoofden en heeren van qualiteit' gebruikt en aan prins Willem I en zijn zonen is het te danken dat de Spaanse tyrannie is afgeworpen en de vrijheid verkregen. De seclusie van de prins en zijn nakomelingen betekent de hoogste ondankbaarheid en miskenning tegenover dit vorstelijk huis. Na dit gevoelsargument komt de afzonderlijke onderhandeling door Van Beverningh en Nieuwpoort ter sprake. Zolang deze met de 'titel en character' van ambassadeurs vanwege de Republiek waren bekleed hadden zij geen afzonderlijke lastgeving mogen aannemen, zeker niet een opdracht die in strijd was met hun instructie, omdat zij uitdrukkelijk waren gelast slechts op basis van het temperament vrede te sluiten.

Vervolgens wordt in de Deductie betoogd dat Holland met zijn handelwijze de Republiek heeft geblameerd. Wanneer met een dergelijk gemak aan de eisen van een vreemde mogendheid werd toegegeven, wat zouden anderen dan niet ten aanzien van geringer personen kunnen eisen. Ook angst voor binnenlandse onenigheid is een overweging. Ieder verkeerde in de mening dat het temperament door Engeland was voorgesteld en dat daarmee de eis tot seclusie geheel was vervallen. Het tegendeel blijkt nu waar te zijn, wat veel misnoegen onder regenten en volk kan veroorzaken:

35. Ibidem, 21 juni 1654. 
nademaal nu het contrarie sigh openbaert, en kan 't selve niet anders als allerhande sinistre impressien ende alteratien causeren in de gemoederen van vele van de regenten, een mishagen nemende in desen cours van affaires ende generalijck van de Gemeente, aen wekkers goede genegentheijt ende opinie tot beleijt ende directie van de zaecken hier te lande, hoe vele is gelegen, konnen best die gene weten, die door lange ervarentheijt het naturel ende aert van deselve wel hebben leren kennen.

Dit was zeker geen goedkoop argument. De Staten van Zeeland hadden de laatste jaren ondervonden dat zij met de publieke opinie terdege rekening moesten houden.

Aan het einde van de Deductie zet Veth uiteen dat Hollands optreden ook in strijd was met de particuliere Unie tussen Holland en Zeeland. Sinds de instelling van de graafschappen had een nauwe band tussen beide gewesten bestaan, die door de Unie tussen Holland en Zeeland in 1575 en 1576 opnieuw was bevestigd. Op grond van deze Unie had Holland met Zeeland overleg moeten plegen, aangezien het hier een zaak van gemeenschappelijk belang betrof. De Zeeuwen waren volgens de Deductie nooit in gebreke gebleven: 'die behoorlijcke conscientie maken van hare verbonden, ende nevens haere ronde Zeeuwsche taele altijdt gheerne voeghen (soo veel doenlijck is) een rondt en oprecht herte'.

Zowel de ontwerpen als de definitieve tekst van de Deductie bewijzen dat Veth zich met hart en ziel voor de verdediging van het standpunt van zijn provincie heeft ingezet. Hoewel hij tot het staatsgezinde kamp behoorde - in de jaren zestig had hij ook een uitstekende verstandhouding met De Witt - heeft hij Hollands optreden naar beste vermogen bestreden, gedreven door de toewijding aan zijn provincie aan wier 'eere ende luyster' hem veel gelegen was, zoals uit de notulen van de Staten van Zeeland tijdens zijn ambtsperiode herhaaldelijk blijkt.

Om de zaak meer gewicht bij te zetten besloten de Staten de Deductie door een speciale deputatie onder leiding van Adriaen Veth in de Staten-Generaal te laten indienen om 'ter eeuwiger memorie aldaer geregistreert te werden'. De Staten van Holland waren inmiddels van dit voornemen op de hoogte; zij trachtten de indiening van de Deductie te voorkomen door de Staten van Zeeland te verzoeken hun schriftelijke uiteenzetting over de zaak af te wachten. Hoewel enkele steden hiertoe wel bereid waren prevaleerde de mening dat de Deductie zonder uitstel moest worden ingediend, wat in de vergadering van de Staten-Generaal van 30 juni inderdaad plaatsvond $^{36}$. Waarschijnlijk hadden de Zeeuwse gedeputeerden een hevig debat met de afgevaardigden van Holland verwacht, maar aangezien hun contradeductie vrijwel gereed was deden dezen er het zwijgen toe, en wat spijtig noteerde Adriaen Veth: 'hier op hebben de Heeren van Hollant niet met allen gesegt tot solutie of debat, maer tselve geheelick gepreterieert ${ }^{37}$.

36. Ibidem, 20 juni 1654; Resoluties Staten-Generaal, 30 juni 1654.

37. RAZ, Verzameling Verheije van Citters, nr. $123 \mathrm{~b}$. 


\section{J. H. KLUIVER}

Dit betekende overigens niet dat de Deductie van Zeeland geen effect sorteerde: de Deductie van Holland, die eind juli verscheen, was in hoofdzaak gericht tegen die van Zeeland. Daaruit blijkt wel hoezeer Holland zich door de verwijten van Zeeland aangesproken voelde. Een veroordeling door deze bondgenoot van het eerste uur woog zwaarder dan een verwijt van enige andere provincie.

De Hollandse Deductie was in naam opgesteld door de commissie tot de Engelse zaken, maar in feite hoofdzakelijk het werk van Hollands raadpensionaris Johan de Witt. De Deductie van Holland is een meesterlijke verdediging tegen de aanvallen van de andere provincies, te meer wanneer men bedenkt dat hij in enkele weken tot stand is gekomen en na de indiening van de Zeeuwse Deductie moest worden aangepast ${ }^{38}$. De Deductie bestaat uit twee gedeelten: in het eerste wordt Hollands handelwijze gerechtvaardigd, in het tweede worden de nadelen en onheilen, die de tegenstanders uit de seclusie voorzagen, weerlegd. Krachtig en zelfverzekerd betoogt De Witt in het eerste deel achtereenvolgens dat Holland op grond van zijn souvereiniteit het volste recht had tot het uitleveren van de Acte van Seclusie, dat het verlenen van de acte niet in strijd was met de Unie tussen Holland en Zeeland of de Unie van Utrecht, dat de provincies niet verplicht waren elkaar op de hoogte te stellen van correspondentie met vreemde mogendheden, dat generaliteitsfunctionarissen ook zaken voor de provinciën afzonderlijk mochten afhandelen, dat afzonderlijke activiteiten ter bevordering van de vrede geoorloofd waren en dat de Acte van Seclusie niet met een voorgaande resolutie van de Staten-Generaal in strijd was. In het tweede deel stelt De Witt dat niemand in een vrije republiek op grond van zijn geboorte enig recht op ambten kan laten gelden, dat de seclusie geen vernedering betekende voor de Republiek, dat de Nederlandse provinciën door een eenhoofdig gezag meest in onenigheid zijn gebracht, dat de oorlog nog zou hebben voortgeduurd, wanneer de Acte van Seclusie niet was verleend, en tenslotte dat de verdiensten van de Oranjes voldoende waren beloond en de Acte geen ondankbaarheid tegenover het Oranjehuis betekende. Het is in het kader van deze bijdrage niet mogelijk de inhoud van De Witts Deductie volledig tot zijn recht te laten komen. De weergave daarvan moet beperkt blijven tot de reacties op de Deductie van Zeeland.

De Witt begint het eerste deel van de Deductie met een 'narratio facti', een relaas van het verloop van de onderhandelingen met Engeland. De strekking daarvan is dat de Staten van Holland pas door een brief van 15 april van Van Beverningh en Nieuwpoort op de hoogte waren gebracht van Cromwell's eis tot uitlevering van een acte tot uitsluiting van de prins van Oranje uit alle toekomstige ambten. De Witt suggereert dat Cromwell wellicht met het temperament genoegen zou hebben genomen, wanneer de provincies de zaak stil hadden gehouden ${ }^{39}$.

38. Knuttel, Catalogus, nr. 7546, 7547.

39. Ibidem, nr. 7546, 22. 
De Hollandse raadpensionaris toont zich in zijn verdediging van het optreden van zijn provincie een bekwaam advocaat. Hij zoekt zijn kracht in een letterlijke interpretatie van de Unie van Utrecht, in het opsommen van precedenten, en een enkele maal door de christelijke ethiek er bij te betrekken. Hij ontkent dat inbreuk zou zijn gemaakt op artikel tien van de Unie: hier was geen sprake van een confederatie of verbond, maar slechts van een 'obligatoire verklaringe'. De conclusie van Veth dat deze acte het gevolg moest zijn van een voorafgaande overeenkomst weerlegt hij met de mededeling dat vooraf geen onderhandelingen tussen Cromwell en 'haer Edel Groot Mogende' hadden plaatsgevonden, wat naar de letter ook juist was: tevoren had slechts overleg met enkele leden van de Staten van Holland plaatsgevonden ${ }^{40}$. In het tweede gedeelte zegt De Witt naar aanleiding van dit punt nog dat de ratificatie van de vrede en de overhandiging van de Acte van Seclusie zo snel achtereen hadden plaatsgevonden dat geen tussentijds overleg met de Staten van Holland mogelijk was geweest en tussen beide handelingen dan ook geen verband kon be$\operatorname{staan}^{41}$.

De Witt neemt stelling tegen de mening dat het ambassadeurs niet geoorloofd zou zijn andere zaken te behartigen. Het was algemeen gebruikelijk dat dezen ook particuliere zaken afhandelden en de aan Van Beverningh en Nieuwpoort meegegeven instructie verbood dit ook niet. Tegenover het verwijt dat artikel negen van de Unie, geen bestand of vrede te sluiten zonder algemeen goedvinden van de provincies, was overtreden, stelt De Witt dat de provincies 'nae de nature van de voors. Unie' verplicht zijn al wat in hun vermogen is tot de vrede bij te dragen. Het zou ook een zeer onchristelijke uitleg zijn van artikel negen van de Unie, te beweren dat de vrede, die God zozeer bevolen heeft, op grond van deze bepaling achterwege had moeten blijven ${ }^{42}$.

Deze stellingen worden gestaafd met tal van precedenten. De meeste daarvan dateren uit het begin van de opstand, zoals onderhandelingen over de aanbieding van de souvereiniteit aan Anjou door een deel van de provincies, het aanstellen van Joachim Ortel en Jacob de Grijse tot agenten in Engeland door Holland, Zeeland, Friesland en Utrecht in 1581 en het afzenden van Hans van der Veeken naar Frankrijk om de vrijlating van eenige Hollandse schepen te bepleiten ${ }^{43}$. Minder talrijk zijn de precedenten van recenter datum, maar onder deze weinige bevond zich een voorbeeld dat tegen Zeeland als een geducht wapen kon worden gehanteerd: het optreden van de Zeeuwse afgevaardigde Johan de Knuyt tijdens de vredesonderhandelingen te Munster. Deze had toen in weerwil van zijn instructie ook onderhandelingen voor Frederik Hendrik gevoerd en in het voor deze gesloten verdrag boven-

40. Ibidem, 25.

41. Ibidem, 68 .

42. Ibidem, 35-38, 40.

43. Ibidem, 28, 29. 


\section{J. H. KLUIVER}

dien nog de souvereiniteit van' Holland geschonden door voor het district Zevenbergen de vrije uitoefening van de katholieke religie toe te staan. Een bijkomstigheid van deze zaak was dat de provincies dit verdrag op 27 december 1647 in de vredesvoorwaarden hadden opgenomen, zonder de inhoud van de overeenkomst te kennen.

De Witt heeft deze zaak op meesterlijke wijze uitgespeeld. Hij noemt dit verdrag als voorbeeld van een overeenkomst die de totstandkoming van een vredestraktaat had vergemakkelijkt. Door dit verdrag van kracht te verklaren hebben de provincies bovendien beschikt over een deel van de souvereiniteit van Holland; zij wagen het nu Holland te veroordelen omdat het 'iets van het hare' aan Cromwell heeft overgedragen. Ook in verband met de vraag of ambassadeurs andere taken mochten uitvoeren grijpt De Witt weer terug op dit precedent. De Knuyt had op last van Frederik Hendrik in strijd met zijn instructie gehandeld: met hun kritiek op het optreden van Van Beverningh en Nieuwpoort blameren de provincies in feite Frederik Hendrik. Tegenover het verwijt dat Holland met het verlenen van de Acte van Seclusie de particuliere Unie met Zeeland had overtreden stelt De Witt dat Zeeland zich met het besluit tot designatie van het opperbevel op de prins van Oranje evenzeer daaraan schuldig had gemaakt ${ }^{44}$.

Het tweede gedeelte van de Deductie, waarin de consequenties van de Acte van Seclusie nader worden bezien draagt meer het karakter van een partijgeschrift dan het eerste. In het eerste hoofdstuk verdedigt De Witt de stelling dat niemand in de Republiek, ook niet de Oranjes, door zijn geboorte enige aanspraak op ambten kan maken. Hij neemt hiermee stelling tegen de opmerking in de Deductie van Zeeland dat de jonge prins prerogatieven heeft 'hem eenichsints aengeboren'. Aan de hand van een aantal voorbeelden uit de geschiedenis maakt hij duidelijk dat een persoonlijk bewind vrijwel steeds in een tyrannie eindigt: de Visconti in Milaan, Julius Caesar in Rome, Pisistratus in Athene en andere voorbeelden van Griekse republieken. Vervolgens loopt De Witt de geschiedenis van de Republiek na: hoe de hertog van Anjou zich van de macht meester had willen maken, hoe prins Willem I souverein had willen worden en juist voordat dit had kunnen plaatsvinden gelukkig door een 'eer en gotloos moordenaar' van het leven werd beroofd! Hoe prins Willem II, ondanks het feit dat hij beëdigd minister van de Staten van Holland was, de wapens tegen een der voornaamste leden had durven opnemen, een onderneming die God echter had verijdeld ${ }^{45}$. Hier werden de gevoelens tegenover het Oranjehuis niet verdoezeld.

De Witt wijst het verwijt van ondankbaarheid, dat in de Deductie van Zeeland en de protesten van Friesland was gedaan, van de hand. Hij stelt dat de verdiensten

44. Ibidem, 40, 37, 38, 19.

45. Ibidem, 46-51. 
van de Oranjes meer dan vergoed zijn met de betalingen door de Staten-Generaal. Met name Friesland, dat de ondankbaarheid in extravagante bewoordingen aan de kaak had gesteld, herinnert hij aan de vele weldaden die Holland en ook Zeeland voor de vrijheid van het land hadden verricht ${ }^{46}$.

Het Hollandse geschrift bereikte de Staten van Zeeland begin augustus. Hoewel de Statenvergadering nog bijeen was, werd de behandeling tot een volgende vergadering uitgesteld. In deze bijeenkomst was overigens wel over de kwestie van de seclusie gesproken. In juli hadden de Staten een brief van Cromwell ontvangen, waarin Holland tegen de aantijgingen van de andere provincies in bescherming werd genomen ${ }^{47}$. Cromwell hield de Staten van Zeeland voor dat sommigen de goede bedoelingen van Holland verkeerd uitlegden; hij voelde zich daarom verplicht hen er op te wijzen dat een hervatting van de oorlog zeer schadelijk zou zijn voor beide republieken en verzocht de maatregelen die de vrede mogelijk hadden gemaakt te handhaven. Zonder deze met name te noemen doelde Cromwell hiermee op de Acte van Seclusie. Deze brief wekte verbazing en verontwaardiging in Zeeland; men veronderstelde zelfs dat Van Beverningh deze op aandringen van Holland voor Cromwell had opgesteld. In hun antwoord betuigden de Staten van Zeeland hun genegenheid tot de vrede, maar gaven tevens in bedekte termen te kennen dat zij de seclusie afkeurden en het geschil hierover als een binnenlandse aangelegenheid beschouwden, waarin anderen zich volgens het volkerenrecht niet behoorden te mengen $^{48}$.

Om Holland nog eens de les te lezen besloot men het antwoord aan Cromwell ter kennis te brengen van de Staten-Generaal

tot een sinceer en heusch bewijs dat de Heeren Staten van Zeeland opreghtelijck ende openhertigh willen gaen sonder yets bedecktelijck of separatelijck buyten kennisse van de Gemeene Regeringe met eenighe uytheemsche Staten te willen handelen of selfs niet eenige brieven van importantie te willen wisselen ${ }^{49}$.

Jammer genoeg voor de Zeeuwen viel deze vertoning in het water, doordat de Staten van Holland wisten dat de brief al eenige dagen voor de presentatie in de Staten-Generaal was afgezonden. $\mathrm{Na}$ de breedvoerige uiteenzetting door de Zeeuwse

\section{Ibidem,71,72.}

47. Knuttel, Catalogus, nr. 7556; Aitzema, Saken van Staet, III, 935.

48. Knuttel, Catalogus, nr. 7558; Aitzema, Saken van Staet, III, 935,936. De betreffende passage in het concept (RAZ, Archief van de Staten van Zeeland, nr. 1602) luidt als volgt: 'dat sij [vreemdelingen of inboorlingen] durven bestaen het gemoet van u hoogheyt met quaetwillige suspicien in te nemen tegen ons, als off wij vijanden waren van de vrede ende dat sij niet ontsien hebben u hoogheyt te bekommeren ten eynde dat hij zijn sorge oock soude willen laeten gaen over het geene hijer gedaen werde, welcke maniere van doen aen alle regenten die kennisse hebben van het volckerenrecht ende de publycke met reden moet suspect gehouden werden'.

49. Not. Zeeland, 6 augustus 1654. 


\section{J. H. KLUIVER}

gedeputeerden in de trant van de hierboven geciteerde resolutie liet Holland aantekenen dat het gaarne enige opmerkingen op de brief had gemaakt, maar dat dit, 'de sake niet meer in sijn geheel sijnde' door de verzending, niet meer mogelijk was $^{50}$.

De briefwisseling met Cromwell heeft ongetwijfeld tot een gematigder houding van Zeeland bijgedragen. In de septembervergaderingen bleef de behandeling van de Hollandse Deductie dan ook achterwege. Toch werden toen de zaak in november ter sprake kwam vrij scherpe adviezen ingediend. Middelburg betoogde in zijn advies dat het onjuist was een dergelijk geschrift in druk uit te geven:

daer door de geheijmenissen en secreten van de regeringhe, met de swackheden gebreecken van dezelve (die men allesints met wijsheijt behoorde te helen en te verbergen) aen een yeder te kennen gegeven en open geleght werden.

Wat de inhoud van de Deductie betreft meende Middelburg dat de oprechte handelwijze van de voorouders in de 'eerste en ongecorrumpeerde tijden' 'veelsints werden verdrayt en bij de haijren getrokken', ook tegen hun eigenlijke strekking geinterpreteerd. Zeer aanstotelijk achtte Middelburg de kwalijke opmerkingen over prins Willem I, die niet alleen zijn persoonlijk bezit maar ook zijn leven had gegeven voor de vrijheid van het land. Het was de stad ook 'smertelijck gevallen' dat de heilzame resoluties van Zeeland verkeerd werden opgevat, met name die van 21 september 1652 betreffende de designatie van het opperbevel aan de prins van Oranje. Middelburg verklaarde deze resolutie te willen handhaven, zonder echter in de functie van luitenant-generaal te voorzien. In deze laatste restrictie is merkbaar dat de staatsgezinde factie door de vrede weer aan invloed had gewonnen. Goes adviseerde in soortgelijke termen en wenste de Hollandse Deductie in overleg met de andere bondgenoten te beantwoorden. De andere steden toonden zich iets terughoudender. Zierikzee was van mening dat men met discretie te werk moest gaan en 'meer water dan oly tot dat ongeluckig vuur brengen'. Men besloot een commissie tot examinatie van de Deductie van Holland te benoemen, waarin vanzelfsprekend Adriaen Veth zitting kreeg ${ }^{51}$. Deze commissie schijnt niet te zijn bijeengekomen. In een vergadering van de Gecommitteerde Raden op 5 februari 1655 stelde de raadsheer Crommon voor de leden van de commissie tijdig bijeen te roepen, om deze in de aanstaande Statenvergadering rapport te laten uitbrengen. De andere leden wensten echter te wachten tot de zaak in de Statenvergadering aan de orde zou wordengesteld ${ }^{52}$. Deze gematigde houdingwerd ongetwijfeldmedeveroorzaaktdoor een tweede brief van Cromwell. In deze brief van 6 oktober sprak Cromwell open-

50. Resoluties Staten-Generaal, 17 augustus 1654.

51. Not. Zeeland, 17 november 1654.

52. Notulen Gecommitteerde Raden, 9 februari 1655, RAZ, Archief van de Staten van Zeeland, nr. 646 . 
lijk zijn afkeuring uit over de door Zeeland ingediende Deductie en waarschuwde opnieuw dat de vrede gevaar zou lopen wanneer niet alle vredesvoorwaarden zouden worden nageleefd ${ }^{53}$. De Franse ambassadeur Chanut vermeldt dat men grote aanstoot nam aan deze brief maar daarvan geen blijk durfde geven om de handel en scheepvaart geen gevaar te doen lopen ${ }^{54}$.

Toch liet Zeeland zich ook na het verschijnen van de Hollandse Deductie niet geheel onbetuigd. Omstreeks november 1654 verscheen een pamflet getiteld: 'Bedenckingen op de Deductie van de Ed. Gr. Mog. Staten van Hollant, Noopende den Artijckel van Seclusie van den Heere Prince van Oraengien', dat onmiskenbaar van Zeeuwse herkomst is en wellicht mede de oorzaak dat het niet meer tot een officieel weerwoord is gekomen ${ }^{55}$. Dat de 'Bedenckingen' van Zeeuwse herkomst zijn, heeft men in de tijd zelf al verondersteld. In een tegenpamflet 'Korte Aenteeckeninge dienende tot Antwoordt op seecker libel genaemt Bedenckingen' etc. wordt opgemerkt dat uit de stijl van de 'Bedenckingen' kan worden opgemaakt dat het geschrift van Zeeuwse herkomst is ${ }^{56}$. Op grond van een dergelijk criterium kunnen wij niet meer oordelen, maar er zijn tal van andere kenmerken die geen twijfel laten bestaan. In het pamflet worden vele specifiek Zeeuwse stokpaardjes bereden, zoals de verovering van de Zuidelijke Nederlanden, door Zeeland tot aan het einde van de tachtigjarige oorlog vurig gewenst, de tegenstand tegen de vrede van Munster ${ }^{57}$, de ergernis over Hollands tegenwerking van steunmaatregelen aan de Westindische Compagnie 'daer soo veel weduwen, weesen ende beste patriotten des landts, sonderlinge in Zeelandt aen vast zijn' ${ }^{158}$, de veroordeling van Hollands optreden in 1618 en $1650^{59}$, en het ressentiment over de grote macht en welvaart van Holland, met name van Amsterdam ${ }^{60}$. Het is opvallend dat de Deductie van Zeeland in dit pamflet niet alleen wordt verdedigd maar in sommige gevallen ook nader uitgelegd. In hun totaliteit wijzen deze kenmerken onmiskenbaar op Zeeuwse herkomst. De auteur van de 'Bedenckingen', in navolging van de 'Korte Aenteeckeninge' hierna met 'Bedencker' aan te duiden, grijpt iedere mogelijkheid tot verdediging van zijn standpunt aan. Waar het gebrekkige staatsrecht tekort schiet neemt hij zijn toevlucht tot het natuurrecht en de christelijke ethiek. Hij tracht de door De Witt opgesomde precedenten in een naar zijn mening juister context te plaatsen of tracht ze als incidentele voorvallen te isoleren en voert weer andere voorbeelden

53. Ibidem, nr. 960.

54. Chanut aan De Brienne, 19 november 1654, AAEP, CP, Hollande, LII, nr. 118, f. 407.

55. Knuttel, Catologus, nr. 7550, 7551.

56. Ibidem, nr. 7660 .

57. Ibidem, nr. 7550, 25.

58. Ibidem, 26.

59. Ibidem, 5 .

60. Ibidem, 4. 


\section{J. H. KLUIVER}

aan om zijn inzichten aannemelijk te maken. Zowel in spitsvondige redeneringen als in kennis van de geschiedenis doet hij niet voor De Witt onder ${ }^{61}$.

In de Bedenckingen is de Deductie van De Witt in grote lijnen gevolgd. De Bedencker kan tegenover de 'narratio facti' uiteraard geen eigen kennis van zaken stellen, maar hij acht deze als een ongecontroleerd getuigenis van een belanghebbende verdacht, te meer daar Holland al sinds 1618 had laten blijken het Oranjehuis niet welgezind te zijn. Holland rekende zich al sinds lang tot de machtigste provincie en Amsterdam heeft steeds 'getendeerd tot preëminente macht en uytstekende gesach boven de andere steden en provinciën, waertegen altijd liggende als een conterpoys het huys Orangien'. Deze situatie in aanmerking genomen, acht de Bedencker het niet te verwonderen dat Hollands beleid was gericht op het uitschakelen van de Oranjes. Waar echter bewijzen voor deze stelling ontbraken, neemt hij zijn toevlucht tot een bewijs uit het ongerijmde: een zo grote wisselvalligheid in het eisen en weer afzien van de seclusie, zoals die uit de 'narratio' naar voren komt, acht hij niet te rijmen met de reputatie van standvastigheid van Cromwell. Ook de veronderstelling dat deze zou vrezen voor een kind van enkele jaren oud, of vertrouwen op de belofte van één provincie acht hij niet met de kwaliteiten van Cromwell in overeenstemming ${ }^{62}$.

Vervolgens komt de absolute vrijheid, waarop Holland het recht tot uitsluiten van de Oranjes baseerde, ter sprake. De Bedencker signaleert een tegenstelling tussen de voorstelling dat extreme nood de seclusie noodzakelijk maakte en de bewering dat Holland hiertoe volkomen vrijheid had. Hij stelt dat niemand volgens het algemeen geldend recht een ongelimiteerde vrijheid heeft. Iedere beschaafde natie is verplicht de natuurwetten te gehoorzamen, christenen moeten dat bovenal. Door het sluiten van unies verliest men een deel van zijn vrijheid. Ook de vrijheid van adviseren is niet onbeperkt: dit mag niet strekken tot schade van het gemenebest. Tijdens de oorlog met Spanje gold het als een misdaad vrede voor te stellen en in Athene werd Cypselus, die aanried de stad aan Xerxes over te geven, door het volk gestenigd ${ }^{63}$.

Naar aanleiding van het derde hoofdstuk, waarin De Witt had betoogd dat Holland zich op de Grote Vergadering van 1651 geen enkele maal voor designatie van de militaire ambten op de jonge prins had uitgesproken, geeft de Bedencker een nadere toelichting op de Deductie van Zeeland: de opmerkingen over Hollands verklaringen op de Grote Vergadering waren bedoeld als een klacht over de wisselvalligheid van deze provincie. In het vierde hoofdstuk komt de Unie tussen Hol-

61. M. Th. Uit den Bogaard, De gereformeerden en Oranje tijdens het eerste stadhouderloze tijdperk (Groningen, 1954) 143-147, oordeelt wat negatief over de Bedenckingen, naar mijn mening ten onrechte.

62. Knuttel, Catalogus, nr. 7550, 4-7.

63. Ibidem, 8-11. 
land en Zeeland ter sprake. Het viel niet te ontkennen dat Zeeland met het besluit tot designatie in 1652 zonder nader overleg met Holland onjuist had gehandeld. Maar wat was erger: deze openlijke handeling van Zeeland, waarbij niemands vrijheid werd geschonden, of de geheime onderhandelingen van Holland waardoor de andere provincies de mogelijkheid werd benomen de prins ooit tot opperbevelhebber over leger en vloot aan te stellen. Zeeland had slechts een stem uitgebracht die de andere provincies volkomen vrijheid liet, Holland had met de Acte van Seclusie een veto uitgesproken ${ }^{64}$.

Het argument dat de seclusie slechts een 'obligatoire verklaring' zou zijn noemt de Bedencker een logomachie. Ook omdat Holland met het verlenen van de Acte van Seclusie een vredesvoorwaarde vervulde was deze handeling in strijd met artikel negen van de Unie, dat in zaken van bestand en vrede eenparigheid van stemmen voorschreef. De door De Witt aangevoerde precedenten uit het begin van de opstand tegen Spanje acht de Bedencker niet relevant: 'dat sulcx is geschiedt op een ander tijdt en heel verscheijden wijse'. En op een andere plaats zegt hij 'de Unie was doen noch jonck en teer'. Minder gemakkelijk was het de meer recente voorbeelden te ontzenuwen, zoals het optreden van Johan de Knuyt te Munster. De Bedencker keurt de handelwijze van deze Zeeuwse afgevaardigde dan ook af. Hij zoekt de fout in de omstandigheid dat de Staten-Generaal hebben toegelaten dat een zo gewichtige opdracht aan één persoon werd verstrekt. Dit was zelfs onbedachtzaam geweest van Frederik Hendrik. Prins Maurits was in 1608 heel wat waakzamer geweest door persoonlijk de besprekingen bij te wonen ${ }^{65}$.

De Bedencker geeft toe dat ambassadeurs ook wel enige particuliere zaken mogen behartigen, maar deze mogen toch niet in strijd zijn met hun instructie. Ook op dit punt wordt een nadere toelichting gegeven op de Deductie van Zeeland: hier had men niet een speciaal artikel in de instructie op het oog, maar het feit dat Van Beverningh en Nieuwpoort de titel van ambassadeurs van de Republiek voerden en uitdrukkelijke last hadden alleen op basis van het temperament vrede te sluiten. Het viel niet te ontkennen dat de destijds door Frederik Hendrik aan De Knuyt gegeven opdracht in strijd was met diens instructie vanwege de Staten-Generaal, maar dit had men destijds door de vingers gezien wegens de grote autoriteit van de prins, een opmerking die staatsgezinde pamflettisten weer ruimschoots stof voor een tegenaanval opleverde. Door toe te geven dat hier inderdaad onjuist was gehandeld tracht de Bedencker de affaire-De-Knuyt als precedent te ontzenuwen: de ene vlek maakt de andere immers niet schoon en het effect was minder ernstig; de religie in het district Zevenbergen betrof slechts een klein deel van de provincie, terwijl de seclusie de hele staat raakte ${ }^{66}$.

64. Ibidem, 12-14.

65. Ibidem, 14-16.

66. Ibidem, 16-27. 


\section{J. H. KLUIVER}

$\mathrm{Na}$ het voorgaande Oranjegezinde betoog wekt het geen verwondering dat in het tweede gedeelte een pleidooi voor een éénhoofdig gezag wordt gehouden. De Bedencker stelt tegenover De Witts voorbeelden van tyrannieën weer andere feiten: te Rome waren families die van vader op zoon het ambt van consul bekleedden, zonder dat daaruit een monarchie was voortgekomen. Venetië heeft steeds zijn vrijheid behouden hoewel de kapiteins-generaal daar vaak uit dezelfde geslachten werden gekozen. Ook voor de Republiek heeft het eenhoofdig gezag nooit gevaren opgeleverd: prins Willem I heeft de souvereiniteit nooit begeerd, prins Maurits was in de gelegenheid zich van de souvereiniteit meester te maken, maar liet deze bij de provincies, evenzo Frederik Hendrik. De eenhoofdige leiding biedt volgens de Bedencker grote voordelen boven de door Holland gepropageerde collegiale regering: het kost vaak moeite een uit vele leden bestaand college tot eensgezindheid te brengen, terwijl bij een aan één persoon gedelegeerd gezag snel beslissingen kunnen worden genomen ${ }^{67}$.

De kwestie van de erfopvolging wordt in het pamflet weer aan de hand van de algemeen geldende normen aannemelijk gemaakt. Het zou evenzeer onrechtvaardig zijn de Oranjes, die zoveel goede diensten aan het land hebben bewezen, voortaan van alle ambten uit te sluiten als een dienstmaagd na jarenlange trouwe dienst uit huis te verstoten. Het zou toch ook niet billijk zijn nazaten van families als de Bickers, Pauw of De Witt voorgoed van alle stedelijke of provinciale ambten uit te sluiten. Dit was een rake opmerking, want in de stedelijke vroedschappen kwam de erfopvolging steeds meer in zwang ${ }^{68}$. De Bedencker eindigt zijn betoog tenslotte met de geschiedenis van Jozef, die door zijn broers uit afgunst werd verkocht aan de Egyptenaren, maar naderhand de redder van het hele huisgezin werd. Zo hoopt hij dat God ook met de Republiek zal handelen ${ }^{69}$.

Het pamflet miste zijn effect niet: het lokte niet minder dan twee tegenpamfletten uit en de Staten van Holland achtten het dermate gevaarlijk dat zij het verboden, een maatregel die zo effectief was dat al spoedig geen exemplaar meer viel te bemachtigen ${ }^{70}$. Het moet veel gelezen zijn, want het is in drie verschillende drukken verschenen. Het belang blijkt ook uit het feit dat Aitzema het pamflet in zijn geheel in zijn Saken van Staet en Oorlog heeft opgenomen. De Witt schrijft in een brief aan Van Beverningh en Nieuwpoort dat de Bedenckingen vermoedelijk door een predikant of onkundige zijn geschreven, na aanvankehjk te hebben verondersteld dat Knijf, een Fries, de auteur was ${ }^{71}$. Dit is zeker geen objectief oordeel, evenmin

67. Ibidem, 27-30.

68. Ibidem, 30-43.

69. Ibidem, 44.

70. Thurloe Papers, II, 715 .

71. De Witt aan Van Beverningh en Nieuwpoort, 27 november 1654, in: Fruin en Kernkamp, Brieven van Johan de Witt, I, 251. 
als soortgelijke kwalificaties in de tegen de Bedenckingen verschenen pamfletten, de 'Korte Aentekeninge' en de 'Wederlegginge'. Uit deze uitlatingen blijkt eerder dat men zich door de inhoud van het pamflet geraakt voelde.

Hoewel het in de regel zeer moeilijk is de herkomst van een pamflet te achterhalen wil ik toch trachten de herkomst van de Bedenckinge na te gaan. Evenals De Witt's Deductie is dit pamflet een typisch partijgeschrift, waarin wordt genivelleerd en gerelativeerd wat niet in de kraam van de auteur te pas komt, en uitgebuit wat ter ondersteuning van het standpunt kan dienen. Hiervoor is al vastgesteld dat het pamflet waarschijnlijk van Zeeuwse herkomst is. De vele zijdelingse opmerkingen die in de loop van het betoog worden gemaakt wijzen in de richting van een Oranjegezinde contra-remonstrant, echter meer een 'politieck' dan een 'ecclesiastieck', en zeker niet een predikant, ondanks de vele Bijbelcitaten. De streng calvinistische inslag blijkt bijvoorbeeld zeer duidelijk uit een passage over de rechtvaardigheid van de oorlog:

wat aengaet den oorloghe, al is hij swaer ende onsoet, als men hem met gerechtigheijt voert, die en is geen slavernij, ten sij men seijde dat justitie oeffenen slavernij ware, want den oorlogh is een exercitie van de hoogste justitie... Daer is een wet God gestelt die men niet breken mach, men moet geen quaet doen om datter goet nyt soude komen ${ }^{72}$.

De geschiedenis van de Republiek beziet de auteur echter meer vanuit staatkundig dan godsdienstig standpunt: zo sniert hij bijvoorbeeld op Dathenus' optreden te Gent en beziet hij het geschil van 1618 hoofdzakelijk als een politiek conflict. Hij stelt de kerk ook nadrukkelijk onder de souvereiniteit van de staat. Wanneer de opstand tegen Spanje ter sprake komt legt hij meer de nadruk op de vrijheid in het algemeen dan op de vrijheid van godsdienst in het bijzonder. De godsdienst is echter wel een zeer belangrijk motiefin zijn program: bij verovering van de Zuidelijke Nederlanden had men daar het licht van de reformatie kunnen verbreiden en in Brazilië lagen hele koninkrijken open voor de ware religie. Zoals reeds opgemerkt hoeven de vele Bijbelcitaten niet te impliceren dat de auteur een predikant was: aan voorbeelden uit de oudheid, in het bijzonder uit de geschiedenis van Israël, werd in de Republiek in de zeventiende eeuw groot gezag toegekend. Ook De Witt heeft in zijn Deductie in ruime mate van voorbeelden uit de geschiedenis van Israël gebruik gemaakt.

Op grond van het feit dat de houding van Zeeland en de Deductie zo nadrukkelijk worden verdedigd zou men kunnen veronderstellen dat Adriaen Veth de auteur is geweest van de Bedenckingen. De verdere inhoud van het pamflet maakt dit echter zeer onwaarschijnlijk. De Bedenckingen zijn tè orangistisch, te monarchaal van strekking om door deze, door de staatsgezinde factie naar voren geschoven Statensecretaris, te kunnen zijn geschreven. Het is niet waarschijnlijk dat Veth zich

72. Knuttel, Catalogus, nr. 7550, 27. 


\section{J. H. KLUIVER}

in een anoniem geschrift nog extremer zou hebben opgesteld dan hij in de officiële reactie uit hoofde van zijn ambt had moeten doen.

We moeten de Bedencker dan ook meer zoeken in het orangistische kamp: een streng calvinistisch regent met grote sympathie voor het Oranjehuis, maar tegelijkertijd een voorstander van de absolute suprematie van de staat over de kerk. Ook geeft hij in zijn betoog blijk van een grote eruditie en een ruime kennis van de geschiedenis van de oudheid en van de Republiek. Een nadere aanwijzing voor de herkomst vormt het in 1650 verschenen pamflet 'Bickerse Beroerte ofte Hollantsche Eclypsis ${ }^{73}$. Dit pamflet bevat dezelfde typische kenmerken als de Bedenckingen: felle uithalen naar de 'Barneveldsche factie', rancune tegen de grote macht van Amsterdam, spijt over de vrede van 1648 en grote ergernis over het tegenwerken van de Westindische compagnie. Nu kan de 'Bickerse Beroerte' met grote waarschijnlijkheid worden toegeschreven aan de factie van Hendrik Thibaut, die in de tragische gebeurtenissen van 1650 een voorname rol speelde. In dit verband lijkt het me dan ook niet onaannemelijk dat ook de Bedenckingen uit deze kring zijn voortgekomen $^{74}$.

Een aantal jaren later was Adriaen Veth in de gelegenheid nog eens op de zaak terug te komen. Na de restauratie van de Stuarts deed Zeeland in 1660 namelijk nog eens een poging Holland tot designatie van het opperbevel op de jonge prins te bewegen. Het was ook ditmaal Veth, die het voorstel in de Staten-Generaal moest bepleiten ${ }^{75}$. Hoewel de rede naar het oordeel van Aitzema en anderen van grote welsprekendheid getuigde, had ze niet het gewenste effect. In deze rede poneerde Veth opnieuw de stelling uit de Deductie van 1654 dat de Nederlandse gewesten steeds van 'hoofden en heeren van qualiteit' gebruik hadden gemaakt. Hij ondersteunt deze stelling met uitspraken die de Staten van Holland in het verleden hadden gedaan en citaten uit Grotius' Outheijt van de Hollantse Republijcque, een werk 'bij U Edel Groot Mogende in grote achtinge ende estime'. In het pleidooi voor de designatie van de militaire ambten op de prins van Oranje komt ook het punt van de erfopvolging weer ter sprake. Hier gebruikt Veth een zelfde argument als in de Bedenckinge te berde was gebracht, namelijk de erfopvolging in stedelijke ' en andere ambten. Hij hanteert het echter in omgekeerde vorm:

ghelijcket oock voor een tastelijck abuys wert gehouden, ja oock bij veelen geklaeght dat ontrent de collatien van ampten caeteris paribus niet principalijck wert gereflecteert op de kinderen van regenten en notable ministers en officieren die haer leven getrouwelijck hebben gedient gehad.

73. 'Bickerse Beroerte ofte Hollantsche Eclypsis tegen den Helderen Dageraedt der Provintie van Hollandt' (Brussel, 1650) ibidem, $n r .6843$.

74. Het zou te ver voeren dit hier nader te adstrueren. Ik hoop dit te doen in een studie over dé houding van de provincie Zeeland inzake vredesonderhandelingen met Spanje.

75. Knuttel, Catalogus, nr. 8362. 
Het verwijt dat Zeeland met het besluit tot designatie in 1652 de Unie tussen Holland en Zeeland zou hebben overtreden wijst Veth van de hand door te stellen dat alle resoluties tot designatie van de militaire ambten op de prins, die Zeeland sinds 1652 had genomen slechts simpele verklaringen waren, geen 'peremptoire dispositieven', onherroepelijke besluiten. Met deze propositie mocht Veth dan toch nog het genoegen smaken enkele stellingen uit zijn Deductie van 1654 te rechtvaardigen.

Het geschil over de Acte van Seclusie heeft belangrijk materiaal voor de geschiedenis van de Republiek opgeleverd. Waar de meningen van de provincies vaak schuil gaan achter de compromis-resoluties van de Staten-Generaal vinden we de standpunten bij deze gelegenheid in extenso opgetekend en in een uitvoerige polemiek nader geadstrueerd. Deze standpunten zijn voor ons belangrijker dan de vraag welke partij het gelijk aan haar zijde had. Wanneer we over het laatste toch een oordeel moeten uitspreken, moet worden gezegd dat de provincies niet ten onrechte tegen Hollands optreden hebben geprotesteerd. Al was niet te bewijzen dat Holland de Unie van Utrecht naar de letter had overtreden, naar de strekking was dit wel het geval. De Unie van Utrecht was in 1654 meer dan het document dat de provincies in 1579 hadden ondertekend. Rondom de Unie was een ongeschreven recht gegroeid, zoals rondom onze grondwet. De provincies waren zich er in het midden van de zeventiende eeuw terdege van bewust dat afzonderlijke onderhandelingen met een vreemde mogendheid niet waren toegestaan. Vanuit dit bewustzijn hebben Friesland en Zeeland hun protesten tegen Hollands handelwijze gelanceerd. Het probleem voor Holland was dat zijn grote macht niet langer in overeenstemming was met de in 1579 vastgestelde positie. Het is dan ook niet te verwonderen dat af en toe ronduit gezegd werd dat het beter was de Unie te verlaten dan zich de wet te laten stellen door de andere provincies. De Franse ambassadeur Chanut bericht dat degenen die in Holland aan het bewind waren zich liever door afscheiding van de Unie zouden handhaven dan door bij de Unie te blijven hun politiek te moeten prijsgeven. Zij voelden zich in hun positie gesteund door Cromwell. De andere provincies voelden zich, volgens het bericht van Chanut, gefrustreerd door de grote macht van Holland. Geen enkel voorstel kon worden aangenomen zonder het goedvinden van deze provincie: 'elle tient la bourse, elle est quasi la maitraisse ${ }^{76}$.

De provincies waren zich van de werkelijke machtsverhouding zeer wel bewust. Zeeland moest protesteren maar wist dat dit weinig effect zou sorteren. Het bleef bij woorden 'gapende, niet bijtende', zoals Aitzema het met zijn gebruikelijk sarcasme uitdrukt ${ }^{77}$. Zeeland stond in deze zaak voor een dilemma: aan de ene kant had het gemeenschappelijke handelsbelangen met Holland, was het op een goede

76. Chanut aan De Brienne, 7 mei 1654, AAEP, CP, Hollande, LIV, nr. 39, f. 124.

77. Aitzema, Saken van Staet, III, 933. 


\section{J. H. KLUIVER}

samenwerking met deze provincie aangewezen, en was het gebaat bij vrede met Engeland, aan de andere kant moest het zich tegen de macht en de concurrentie van Holland te weer stellen. Voor het laatste was een krachtig generaliteitsgezag vereist, uitgeoefend door de Oranjes. Dit bracht een pragmatische Oranjegezindheid met zich mee, die samenging met een principiële Oranjegezindheid. Deze leefde echter onder het volk en de predikanten veel sterker dan bij de regenten. De publieke opinie heeft in het optreden van Zeeland in deze jaren een sterke rol gespeeld, maar de politiek van de provincie werd zeker niet uitsluitend door angst voor binnenlandse onlusten ingegeven. Het ging hier om een zaak van fundamenteel belang, zoals in 1650 het geschil over de afdanking van troepen. Men moet ook ditmaal Hollands handelwijze hebben aangevoeld als een poging het door de Oranjes belichaamde generaliteitsgezag van zich af te schudden om het eigen provinciaal belang des te beter te kunnen laten prevaleren. Bij alle wrok en frustratie die al bestond over de kolossale toeneming van rijkdom, macht en aanzien van Holland, was dit gevoel voldoende om uiterst felle reacties op het optreden van Holland op te roepen, reacties die echter niet door daden konden worden bekrachtigd doordat een vreemde mogendheid bij het conflict betrokken was en het handelsbelang een krachtiger optreden verbood. Zeeland mocht evenwel het genoegen smaken zijn integriteit te zien gehandhaafd: het genoot de voordelen van de vrede maar had daarvoor niet zijn trouw aan Oranje behoeven te verloochenen. Zo geeft het geschil rondom de Acte van Seclusie een karakteristiek beeld van de positie van Zeeland tegenover Holland en de andere provincies. 


\section{De Jansenistische achtergronden van P. F. de Neny's streven naar een 'Belgische Kerk'*}

\section{J. ROEGIERS}

De verhouding tussen Kerk en Staat in de zeventiende-eeuwse Spaanse Nederlanden kan niet bestudeerd worden zonder voldoende aandacht te schenken aan de acties van jansenistische en anti-jansenistische groepen die beiden een beroep deden op de burgerlijke overheden om hun standpunt te doen zegevieren. Beide partijen verschaften zo de wereldlijke machteen hele reeks gelegenheden om haar macht over kerkelijke zaken uit te breiden. De gouvernementele en gerechtelijke praktijk resulteerden bijvoorbeeld in een stevig uitgewerkte wetgeving op het aanvaarden en publiceren van pauselijke stukken in de Nederlanden, het placetrecht ${ }^{1}$. De landvoogden en de koning waren niet altijd even haastig om in deze twisten op te treden en kozen uiteindelijk meestal partij voor het Romeinse kamp. Met heel wat meer enthousiasme wierpen de Geheime Raad en de provinciale justitieraden zich in de strijd en van het begin af aan schaarden zij zich vaak aan de zijde van de jansenisten.

Voor de koning en zijn landvoogd kwam het er meestal op aan de goede betrekkingen met Rome niet onnodig in het gedrang te brengen; hun optreden werd heel vaak ingegeven door actuele diplomatieke overwegingen. De raden toonden zich meer beginselvast. Sinds de Bourgondische tijd hadden zij zich opgeworpen als de bewakers zowel van de nationale vrijheden van onze provincies als van de souvereine rechten van het staatsgezag. Hun voortdurende zorg voor het veilig stellen van deze rechten van de vorst tegen mogelijke inbreuken daarop door de geestelijkheid en tegen de aanspraken van het Romeinse centraliserende gezag, had een regalistische traditie doen ontstaan die in deze milieus voortdurend levendig bleef dank zij de grote continuïteit die deze instellingen kenmerkte ${ }^{2}$. Het was precies op

* Dit artikel is de uitgewerkte tekst van een lezing gehouden op het 43e congres van de Federatie der Kringen voor Geschiedenis, Oudheidkunde en Folklore van België, te St.-Niklaas in augustus 1974. Voor bibliografische aanwijzingen ben ik veel dank verschuldigd aan Prof. dr. Elisabeth Kovács, Wenen.

1. Zie L. Willaert, 'Le placet royal aux Pays-Bas', Revue belge de philologie et d'histoire, XXXII (1954) 466-506, 1075-1117; XXXIII (1955) 20-36.

2. Ibidem, 478: 'Ces Conseils groupent, outre les grands seigneurs du Conseil d'Etat, des légistes tres au fait de la jurisprudence et des libertés nationales, gardes qui veillent jalousement aux barrières de la loi. Ils ne perdent jamais leurs membres qu'individuellement, un à un; ils ne sont donc pas, comme le roi, mortels. A l'abri de cette main-morte laïque, 1'administration accumule une puissance qui se fortifie progressivement'. 